\title{
Ylidic polyfunctionalized compounds with a diazinium skeleton
}

\author{
Maria C. Caprosu, Mioara A. Andrei, Geanina C. Mangalagiu, Magda Ghe. Petrovanu, \\ and Ionel I. Mangalagiu* \\ “Al.I.Cuza” University, Department of Organic Chemistry, Bd. Copou, No. 11, Iasi-6600, \\ Romania \\ E-mail: ionelm@uaic.ro
}

\section{Dedicated to Kjell Undheim, Oslo, on the occasion of his $70^{\text {th }}$ birthday (received 16 Feb 01; accepted 19 Mar 02; published on the web 27 Mar 02)}

\begin{abstract}
For the first time in the cycloimmonium ylide series we have obtained unsaturated styryl carbanion monosubstituted ylides. These ylides, phthalazinium- and 4-methylpyrimidiniumylides, have polyfunctionalized character: ylide and alkene. In this paper we have exploited only the ylidic character. The ylides $\mathbf{3}$ and $\mathbf{4}$ have been proven to have 1,3-dipole characters (3a and 4a), respectively. Thus, the ylides function as 1,3-dipoles in 3+2 dipolar cycloaddition reactions with various dipolarophiles (such as DMAD, NPM). The structure of all the other compounds (salts and cycloadducts) has been proven through elemental and spectral (IR, NMR) analysis. The in vitro biological activity of the newly obtained phthalazine and pyrimidine compounds was also tested. Some of them have proved to have a remarkable activity against different microorganisms (germs and fungus). Correlation of the structure-biological activity has been studied.
\end{abstract}

Keywords : Cycloimmonium ylides, diazine, phthalazine, pyrimidine, cycloaddition, polyfunctionalized compounds, biological activity: antimicrobial and antifungical

\section{Introduction}

The chemistry of cycloimmonium ylides has been widely discussed. ${ }^{1,2,3}$ The research has focused especially of the ylides of type I. Few studies have been done concerning the ylides II and III.(Scheme 1) 


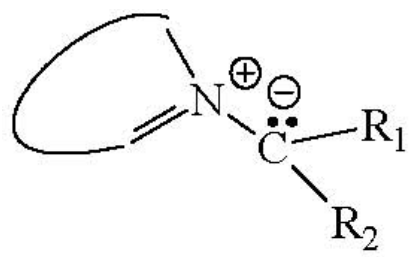

I

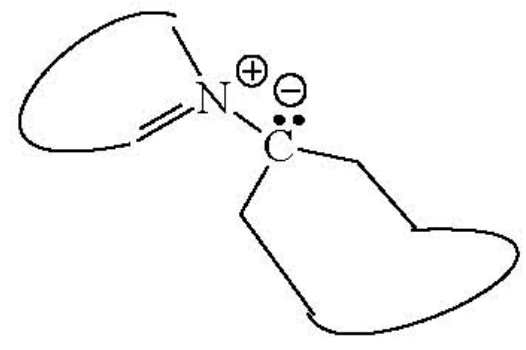

II

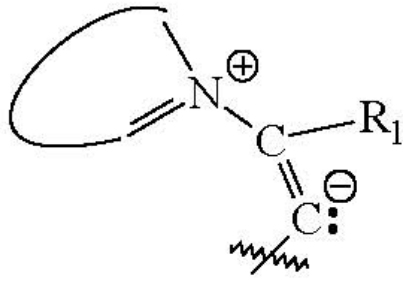

III

\section{Scheme 1}

In the early 70s Acheson and Foxton ${ }^{4}$ assumed, for the first time in the diazine series, the existence of ylides with unsaturated carbanion.(Scheme 2)

Since then no other research has been done in the field of diazinium ylides with unsaturated carbanion although this is a convenient way to acces polyfunctionalized compounds with a ylidic skeleton.

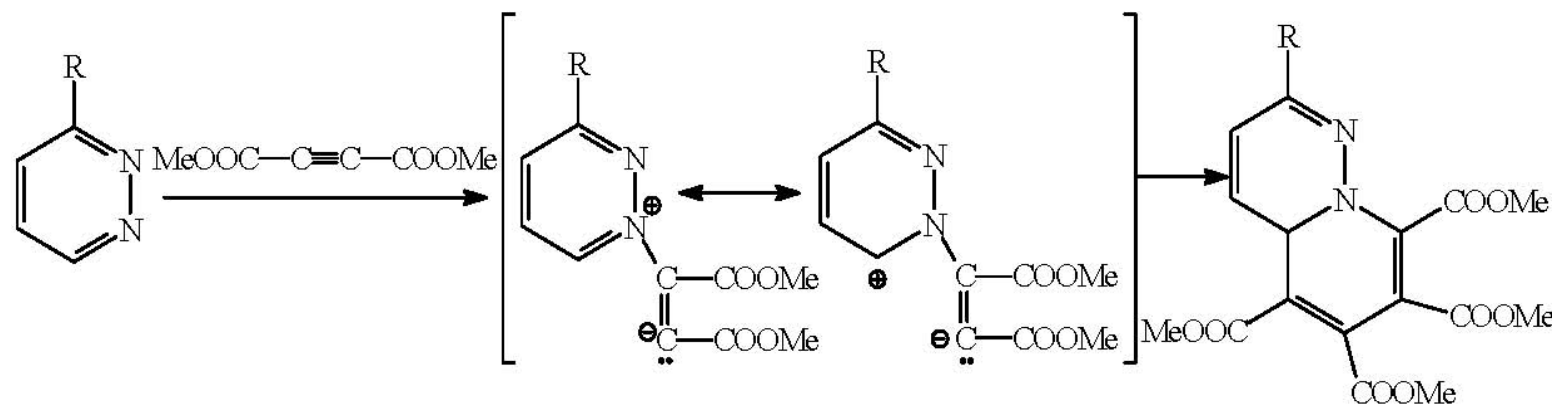

\section{Scheme 2}

The emphasis of this work was, on one hand, to get ylides with a new type of unsaturated carbanion (analogous with III) and, on the other hand, to get polyfunctionalized compounds with a ylidic skeleton. Another goal was to test the biological activity of the new compounds.

\section{Results and Discussion}

In first instance we tried to get phthalazinium- (3) and pyrimidinium- (4) ylides with unsaturated carbanion, using an adaptation of the Krönke ${ }^{5}$ salts method (Scheme 3). Thus, the reactions of phtalazine and 4-methylpyrimidine with cinnamyl bromide yield to the salts $\mathbf{1}$ and $\mathbf{2}$, respectively. The structures were characterised by elemental and spectral analysis. The dehydrohalogenation of 1 and 2 with $40 \%$ aqueous potassium carbonate lead (according to the TLC) to a mixture of two compounds with a structure impossible to be determined through 
elemental and spectral analysis. We assumed initially one of the compound to be ylide (3a respectively 4a) and the other one the dimeric structure ( 3 ' and 4') formed via a $3+3$ dipolar cycloaddition of $3 \mathbf{c}$ and $\mathbf{4 c}$, respectively. Schema 4 (however, further study concerning these compounds remains to be done).
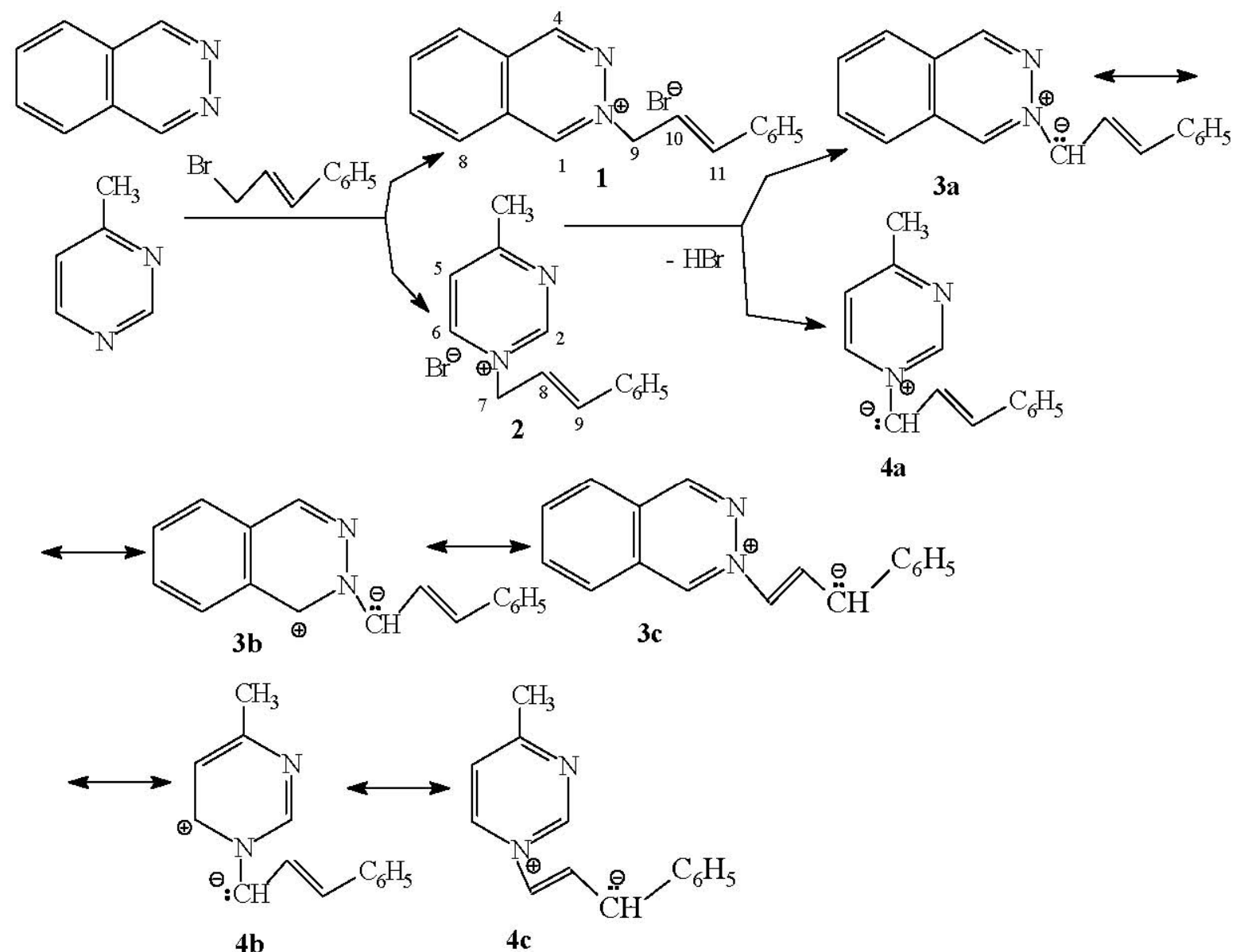

\section{Scheme 3}

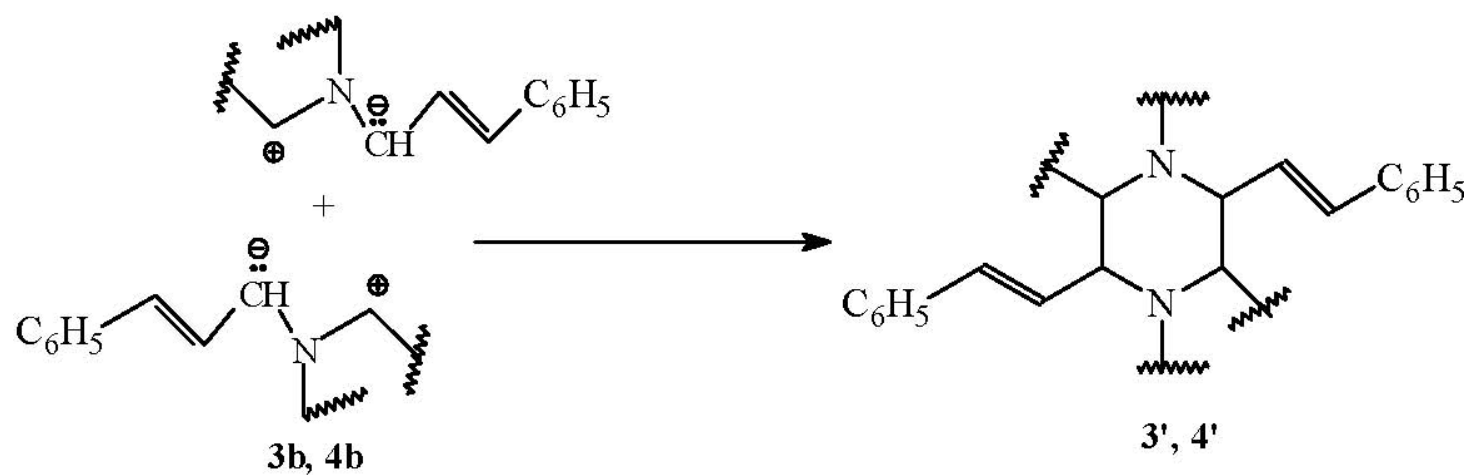

\section{Scheme 4}


Because of the unsatisfactory on the elemental and spectral analysis, in order to elucidate the structure of ylides $\mathbf{3}$ and $\mathbf{4}$ (but also in order to get new azabicycles compounds) we underwent chemical proves. Thus, we treated ylides $\mathbf{3}$ and $\mathbf{4}$, generated in situ, with different dipolarophiles such as DMAD and N-phenylmaleimide (NPM), Schema 5. If the ylides have a 3a respectively 4a structures (having in view that they could accept the canonical structures $\mathbf{3 b}$ and $\mathbf{4 b}$ ), they should function as 1,3-dipoles giving 3+2 dipolar cycloaddition reactions. If the ylides have a 3c respectively 4c structure, they should function as 1,5-dipoles giving 5+2 dipolar cycloaddition reactions. Experimentally we have found that styryl ylides $\mathbf{3}$ and $\mathbf{4}$, in reaction with DMAD or/and NPM, give $3+2$ cycloadditions reactions. This means that the ylidic structures 3a respectively $\mathbf{4 a}$ are the real one.

As it can be seen in Scheme 5 in reaction with DMAD we got the $3+2$ azabicyclic compounds 5 and 6. In the case of NPM the reaction took place only with phthalazinium ylide leading to the $3+2$ cycloadduct 7 while pyrimidinium ylide did not react (the last one being less reactive ${ }^{6}$.

The structure of the compounds $\mathbf{1 , 2 , 5 , 6 , 7}$ has been proven through elemental $(\mathrm{N} \%)$ and spectral (IR, $\left.{ }^{1} \mathrm{H}-\mathrm{NMR},{ }^{13} \mathrm{C}-\mathrm{NMR}\right)$ analysis.

The salts 1 and 2: The IR spectra: the most important signals are those of the $\mathrm{C}=\mathrm{C}$ alkene double bound: $v=1630 \mathrm{~cm}^{-1}$ (intense) in compound 1 respectively at $v=1640 \mathrm{~cm}^{-1}$ (intense) in compound 2. In the ${ }^{1} \mathrm{H}-\mathrm{NMR}$ spectra the most important signals are those of the $\mathrm{CH}_{2}$ group and ethenyl protons. The $\mathrm{CH}_{2}$ protons appear at $\delta=5.90-5.70 \mathrm{ppm}(2 \mathrm{H}, \mathrm{d}, \mathrm{J}=5.0 \mathrm{~Hz})$ in 1 respectively at $\delta=5.60-5.30 \mathrm{ppm}(2 \mathrm{H}, \mathrm{d}, \mathrm{J}=5.0 \mathrm{~Hz})$ in 2 . The ethenyl protons appear in compound 1 at $\delta=7.10-6.70 \mathrm{ppm}\left(1 \mathrm{H}_{10}, \mathrm{q}, \mathrm{J}=5.0 \mathrm{~Hz}, \mathrm{~J}=10.0 \mathrm{~Hz}\right)$ and $\delta=7.40-7.10 \mathrm{ppm}\left(\mathrm{H}_{11}, \mathrm{~d}, \mathrm{~J}=10.0 \mathrm{~Hz}\right)$, respectively in compound 2 at $\delta=6.70-6.40 \mathrm{ppm}\left(\mathrm{H}_{8}, \mathrm{q}, \mathrm{J}=5.0 \mathrm{~Hz}, \mathrm{~J}=10.0 \mathrm{~Hz}\right]$ and $\delta=7.00-6.70$ $\operatorname{ppm}\left(\mathrm{H}_{9}, \mathrm{~d}, \mathrm{~J}=10.0 \mathrm{~Hz}\right)$.

Pyrrolo-diazine cycloadducts 5 and 6: In the IR spectra the signals corresponding to CO ester groups appear at $1750-1700 \mathrm{~cm}^{-1}$. The signals are very strong and broaded with 2 maximum: $1740 \mathrm{~cm}^{-1}\left(v_{\mathrm{C}=\mathrm{O}, \mathrm{Me} 2}\right)$ and $1725 \mathrm{~cm}^{-1}\left(v_{\mathrm{C}=\mathrm{O}, \mathrm{Me} 1}\right)$ in 5 and respectively at $1735 \mathrm{~cm}^{-1}\left(v_{\mathrm{C}=\mathrm{O}, \mathrm{Me} 5}\right)$ and $1720 \mathrm{~cm}^{-1}\left(v_{\mathrm{C}=\mathrm{O}, \mathrm{Me} 6}\right)$ in 6 . In the ${ }^{1} \mathrm{H}$ NMR spectra the most important evidence for pyrrolophthalazine 5 and pyrrolopyrimidine 6 structures are the following : - the rings are aromatized because of the missing signals corresponding to saturated protons; - the ethenyl protons appear at chemical shifts and with coupling constants in accordance with the proposed structures, in trans. In compound 5 proton $\mathrm{H}_{11}$ appear at $\delta=4.30-4.25 \mathrm{ppm}(\mathrm{d}, \mathrm{J}=13.4 \mathrm{~Hz})$ and $\mathrm{H}_{12}$ at $\delta=4.86-4.82 \mathrm{ppm}(\mathrm{d}, \mathrm{J}=13.4 \mathrm{~Hz})$. In comound 6 proton $\mathrm{H}_{8}$ appear at $\delta=4.30-4.10 \mathrm{ppm}(\mathrm{d}$, $\mathrm{J}=13.0 \mathrm{~Hz})$ and $\mathrm{H}_{9}$ at $\delta=5.00-4.80 \mathrm{ppm}(\mathrm{d}, \mathrm{J}=13.0 \mathrm{~Hz})$; - the Me ester groups appear as non equivalent because of the different magnetic vicinity. Thus, in compound 5 the group $\mathrm{Me}_{1}$ appear at $3.71 \mathrm{ppm}(\mathrm{s})$ and $\mathrm{Me}_{2}$ at $3.81 \mathrm{ppm}(\mathrm{s})$, while in compound 6 the group $\mathrm{Me}_{5}$ appear at $3.30 \mathrm{ppm}$ (s) and $\mathrm{Me}_{6}$ at $3.80 \mathrm{ppm}(\mathrm{s}) .{ }^{13} \mathrm{C}$ NMR spectra of compound 5 confirm also the structure: 175.9 ppm $\left(\mathrm{C}_{1 \mathrm{a}}\right.$, ester with conjugation), $174.1 \mathrm{ppm}\left(\mathrm{C}_{2 \mathrm{a}}\right.$, ester with conjugation), $52.73 \mathrm{ppm}\left(\mathrm{Me}_{2}\right.$ ester), $51.14 \mathrm{ppm}$ ( $\mathrm{Me}_{1}$ ester). These data confirm, as well as the ${ }^{1} \mathrm{H}-\mathrm{NMR}$, the different magnetic vicinity of the two ester groups. The ethenyl carbons appear at $127.35 \mathrm{ppm}\left(\mathrm{C}_{12}\right)$ 
and126.26 ppm $\left(\mathrm{C}_{11}\right)$.

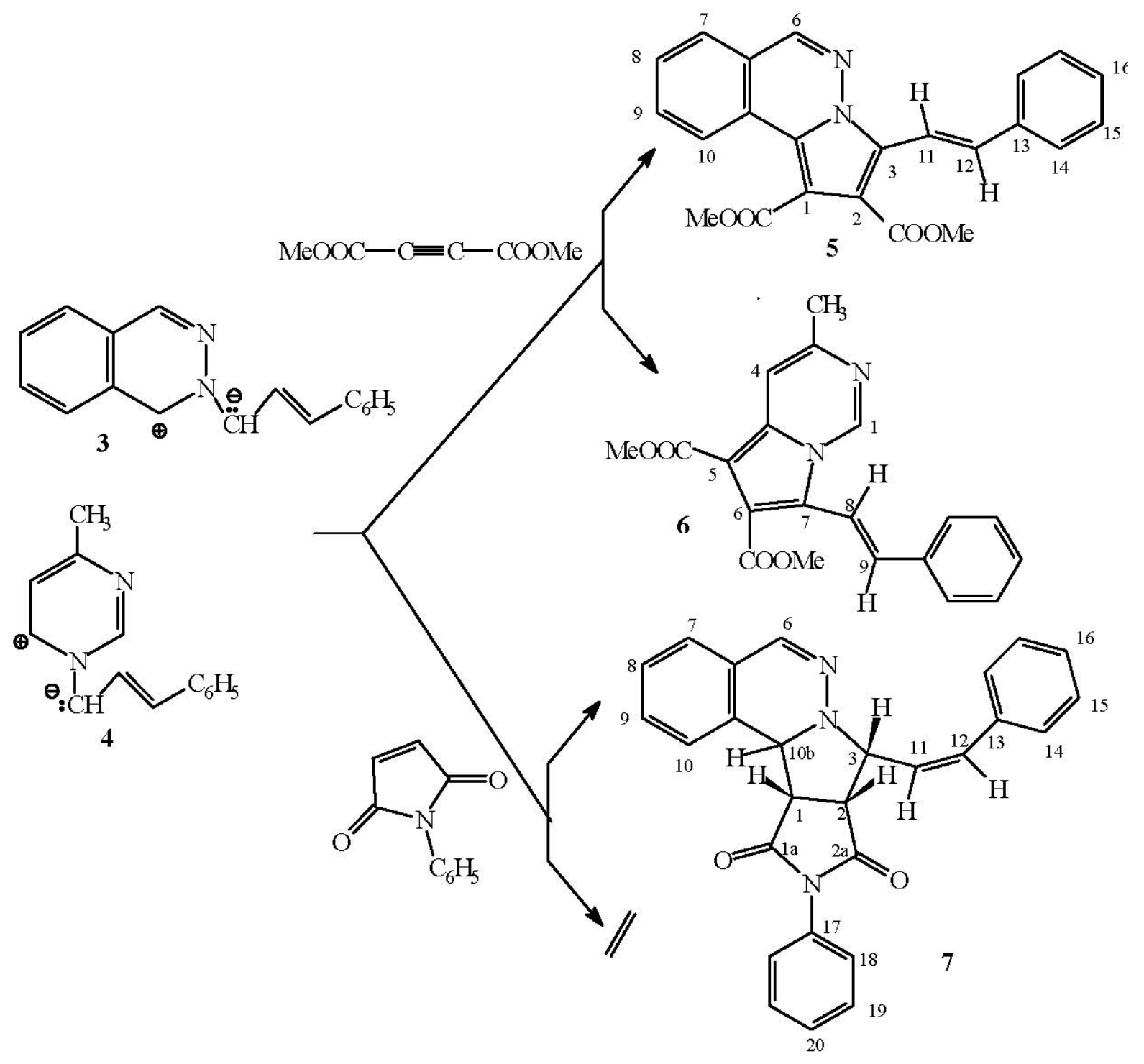

\section{Scheme 5}

Cycloadduct 7: In the IR spectra the signals corresponding to $\mathrm{CO}$ imide groups appear at $1750-1680 \mathrm{~cm}^{-1}$. The signals are very strong and broaded with 2 maximum: $1735 \mathrm{~cm}^{-1}$ and 1715 $\mathrm{cm}^{-1}$. In the ${ }^{1} \mathrm{H}-\mathrm{NMR}$ spectra the most important signals are those of the protons $\mathrm{H}_{1}, \mathrm{H}_{2}, \mathrm{H}_{3}, \mathrm{H}_{10 \mathrm{~b}}$, $\mathrm{H}_{11}$ and $\mathrm{H}_{12}$. The ethenyl protons, $\mathrm{H}_{11}$ and $\mathrm{H}_{12}$, appear with different chemical shifts and coupling constants: $\mathrm{H}_{12}$ at 4.83-4.80 ppm $(\mathrm{d}, \mathrm{J}=7.6 \mathrm{~Hz})$ and $\mathrm{H}_{11}$ at 4.24-4.12 ppm (t, $\mathrm{J}=7.6 \mathrm{~Hz}$, $\mathrm{J}=15.2 \mathrm{~Hz}$ ). These coupling constants prove, on one hand, that the ethenyl protons are in cis and, on the other hand, that $\mathrm{H}_{11}$ is in trans with $\mathrm{H}_{3}$ (which appear at 4.41-4.32 ppm, triplet and doublet, $\mathrm{J}=15.2 \mathrm{~Hz}, \mathrm{~J}=7.1 \mathrm{~Hz}, \mathrm{~J}=1.8 \mathrm{~Hz}$ ). Protons $\mathrm{H}_{2}(3.79-3.74 \mathrm{ppm}$, dd, $\mathrm{J}=6.5 \mathrm{~Hz}, \mathrm{~J}=7.1 \mathrm{~Hz}$ ), $\mathrm{H}_{1}\left(3.71-3.65 \mathrm{ppm}\right.$, triplet and doublet, $\mathrm{J}=6.5 \mathrm{~Hz}, \mathrm{~J}=8.1 \mathrm{~Hz}, \mathrm{~J}=1.8 \mathrm{~Hz}$ ) and $\mathrm{H}_{3}$ are on the same 
side of the pyrrolophthalazine ring. $\mathrm{H}_{10 \mathrm{~b}}$ appear at 5.09-5.00 ppm (d, J=8.1 Hz). ${ }^{13} \mathrm{C}$ NMR spectra of compound 7 confirm also the structure: 176.84 ppm $\left(\mathrm{C}_{2 \mathrm{a}}, \mathrm{CO}\right.$ imide $), 174.76 \mathrm{ppm}\left(\mathrm{C}_{1 \mathrm{a}}\right.$, $\mathrm{CO}$ imide). The ethenyl carbons appear at $125.53 \mathrm{ppm}\left(\mathrm{C}_{12}\right)$ and122.67 ppm $\left(\mathrm{C}_{11}\right)$.

All the remaining signals from IR and NMR spectra are in accordance with the proposed structure of the compounds $\mathbf{1 , 2 , 5 , 6 , 7}$.

The in vitro antimicrobial and antifungical activity of the newly obtained phtalazine and 4methylpyrimidine compounds was tested having in view that our previous study has proven a certain biological activity in this respect to related compounds. ${ }^{7,8,9}$

The test was performed using the diffusimetric method ${ }^{10}$ with rustlessteel cylinders based on the diffusion of the tested substances on the gelose surface (for bacteria) and Sabouard environment (for fungus Candida albicans). The cylinders were maintained $24 \mathrm{~h}$ at thermostat, at $34{ }^{0} \mathrm{C}$ for bacteria and at $37{ }^{0} \mathrm{C}$ for Candida. The tested substances were previously disolved in DMFA 5\% (v/v). A witness solvent sample has been done. The inhibition diameter zone, in $\mathrm{mm}$, of development of microbial strain was measured. It is considered active ${ }^{11}$ a compound for which the difference between the inhibition diameter zone of compound and witness is up to 2 mm (3-4 mm moderate active and up to 5 very active). The results are listed in Table 1.

Table 1. Results of in vitro antimicrobial and antifungical activity for some phthalazine and 4methylpyrimidine derivatives described in the text

\begin{tabular}{|c|c|c|c|c|c|}
\hline $\begin{array}{c}\text { Strain } \rightarrow \\
\text { Product } \\
\downarrow\end{array}$ & $\begin{array}{c}\text { Staphylococcus aureus } \\
\text { Oxford }\end{array}$ & $\begin{array}{c}\text { Escherichia } \\
\text { coli }\end{array}$ & $\begin{array}{l}\text { Bacillus } \\
\text { subtillis }\end{array}$ & $\begin{array}{l}\text { Bacillus } \\
\text { proteus }\end{array}$ & $\begin{array}{l}\text { Candida } \\
\text { albicans }\end{array}$ \\
\hline Witness & 17 & 18 & 18 & 17 & 18 \\
\hline 1 & 22 & 23 & 21 & 23 & 17 \\
\hline 2 & 23 & 21 & 24 & 23 & 20 \\
\hline 3 & 21 & 17 & 20 & 16 & 21 \\
\hline 4 & 24 & 22 & 23 & 23 & 24 \\
\hline 5 & 21 & 20 & 19 & 18 & 15 \\
\hline 6 & 20 & 20 & 19 & 18 & 16 \\
\hline 7 & 20 & 15 & 20 & 18 & 15 \\
\hline
\end{tabular}

The comparative analysis of the obtained data (Table 1) leads to the following conclusions concerning the relation between structure and biological activity: - both type of salts, 1 (from phthalazine) and 2(from pyrimidine), have a remarkable non selective activity against Gram positive and Gram negative germs; - cycloadducts 5, 6 and 7 have a moderate activity against germs; - either the salts and cycloadducts are less active or inactive against fungus Candida; - we decide to test and the mixture ylide-dimer $\mathbf{3}$ and $\mathbf{4}$. The mixture ylide-dimer $\mathbf{4}$ from pyrimidine prove to be very, very active having a remarkable non selective activity against germs and also against fungus Candida; - if we compare the compounds from the two series, phthalazine and 
pyrimidine, we notice that the pyrimidine compounds are more active.

\section{Conclusions}

For the first time in the cycloimmonium ylides we have obtained styryl carbanionmonosubstituted ylides. These ylides, phthalazinium- and 4-methylpyrimidiniumylides, have polyfunctionalized character: ylide and alkene. In this paper we exploited only the ylidic character.

Five new diazine compounds $(\mathbf{1}, 2,5,6,7)$ were synthesized. The structure of these compounds (salts and cycloadducts) has been proven through elemental and spectral analysis. The structure of the ylides $\mathbf{3}$ and $\mathbf{4}$ has been proven to be of type 3a respectively $\mathbf{4 a}$ through chemical ways (however, we classify these compounds as hazardous).

The in vitro biological activity of the newly obtained phthalazine and pyrimidine compounds was tested. Some of them proved to have a remarkable activity against different microorganisms (germs and fungus). Correlation of the structure-biological activity has been studied.

\section{Experimental Section}

General Procedures. ${ }^{1} \mathrm{H}$ - and ${ }^{13} \mathrm{C}$ - NMR spectra were run on a Varian Gemeni $200 \mathrm{MHz}$ and Bruker $80 \mathrm{MHz}$ spectrometer and were recorded in ppm downfield from an internal standard, $\mathrm{SiMe}_{4}$ in $\mathrm{CDCl}_{3}$. The coupling constants are given in $\mathrm{Hz}$. The IR spectra were recorded with a SPECORD-71 spectrometer in $\mathrm{KBr}$. The melting points are uncorrected.

$N$-Cinnamyl phthalazinium bromide (1). Phthalazine $(10 \mathrm{mmol})$ was suspendend in $30 \mathrm{ml}$ anhydrous benzene and, then, cinnamyl bromide $(10 \mathrm{mmol}$ dissolved in $20 \mathrm{ml}$ anhydrous benzene) was added. The solution was stirred at room temperature for $3 \mathrm{~h}$. Recrystallized from acetone-acetonitrile afforded white crystals. Yield 96\%, m.p. $179-180{ }^{\circ} \mathrm{C}$. Anal. $\mathrm{C}_{17} \mathrm{H}_{15} \mathrm{BrN}_{2}$ : C: Calcd. 62.38, Found 62.20; H: Calcd. 4.58, Found 4.50; N: Calcd. 8.56, Found 9.00. IR (KBr, $\mathrm{cm}^{-1}$ ): v: 1630(s), 1600, 1570, 1505, 1470 (s-m), 1290 (s), 2900 (w). ${ }^{1} \mathbf{H}$ NMR $\delta: 10.80\left(\mathrm{~s}, \mathrm{H}_{1}\right)$, $10.10\left(\mathrm{~s}, \mathrm{H}_{4}\right), 8.80-8.35$ (m, 4H: $\left.\mathrm{H}_{5}, \mathrm{H}_{6}, \mathrm{H}_{7}, \mathrm{H}_{8}\right), 7.60-7.20$ (m, 5H, $\left.\mathrm{C}_{6} \mathrm{H}_{5}\right), 7.40-7.10$ (d, $\mathrm{H}_{11}, \mathrm{~J}=$ 10.0), 7.10-6.60 (q, $\left.\mathrm{H}_{10}, \mathrm{~J}=10.0, \mathrm{~J}=5.0\right), 5.90-5.70$ (d, $\left.\mathrm{H}_{9}, \mathrm{~J}=5.0\right)$.

$\mathrm{N}$-Cinnamyl pyrimidinium bromide (2). 4-Methylpyrimidine $(10 \mathrm{mmol})$ and cinnamyl bromide (10 $\mathrm{mmol}$ ) was dissolved in $10 \mathrm{ml}$ acetone. The solution was left (stirring intermittently) for 7 days at room temperature, then filtered and washed thoroughly with ethyl ether. Recrystallized from acetone-ethyl ether. Yellow-redish crystals. Yield 89\%, m.p. 108-110 ${ }^{\circ} \mathrm{C}$. Anal. $\mathrm{C}_{14} \mathrm{H}_{15} \mathrm{BrN}_{2}$ : C: Calcd. 57.63, Found 57.60; H: Calcd. 5.15, Found 5.10; N: Calcd. 9.62, Found 9.10. IR (KBr, cm $\left.{ }^{-1}\right)$ : v: 1640(s), 1560, 1505, 1470 (s-m), 1290 (s), 2900 (w), 31003000(w). ${ }^{1} \mathbf{H}$ NMR $\delta: 11.80\left(\mathrm{~s}, \mathrm{H}_{2}\right), 10.10-9.90$ (d, $\left.\mathrm{H}_{6}, \mathrm{~J}=6.0\right), 9.60-9.40\left(\mathrm{~d}, \mathrm{H}_{5}, \mathrm{~J}=6.0\right), 7.60$ - 
$7.15\left(\mathrm{~m}, 5 \mathrm{H}, \mathrm{C}_{6} \mathrm{H}_{5}\right), 7.00-6.70\left(\mathrm{~d}, \mathrm{H}_{9}, \mathrm{~J}=10.0\right), 6.70-6.40\left(\mathrm{q}, \mathrm{H}_{8}, \mathrm{~J}=10.0, \mathrm{~J}=5.0\right)$ ), 5.60-5.30 (d, $\left.\mathrm{H}_{7}, \mathrm{~J}=5.0\right)$.

General procedure to obtain diazinium ylides. Salt 1 or $2(1 \mathrm{mmol})$ was dissolved in $50 \mathrm{ml}$ water and treated with an aqueous solution of $\mathrm{K}_{2} \mathrm{CO}_{3} 40 \%$ when the ylide was obtained. The ylide was filtered to vacuum, washed with a great amount of water and dried to vacuum.

Phthalazinium cinnamyl methylide (3). CAUTION: hazardous compound! According to General Procedure using compound 1. Cream compound. Yield 99\%, m.p. 77-80 ${ }^{\circ} \mathrm{C}$. Anal. $\mathrm{C}_{17} \mathrm{H}_{14} \mathrm{~N}_{2}$ (for ylide): N: Calcd. 11.02, Found 11.38. IR (KBr): v: 1660-1635(s, broaded, with 2 maximum: 1655 and 1645), 1600, 1500, 1465, 1410 (s-m), 1165 (s), 2900 (w).

4-Methylpyrimidinium cinnamyl methylide (4). CAUTION: hazardous compound! According to General Procedure using compound 2. Pink compound. Yield 99\%, m.p. 60-65 ${ }^{\circ} \mathrm{C}$. Anal. $\mathrm{C}_{14} \mathrm{H}_{14} \mathrm{~N}_{2}$ : N: Calcd. 13.46, Found 13.80. IR (KBr): v: 1690-1640(s, broaded, with 2 maximum: 1670 and 1650), 1580, 1500, 1470, 1420 (s-m), 1150 (s), 2900 (w), 3100-3000(w).

General procedure to obtain $3+2$ cycloadducts. The cycloimmonium salt $(10 \mathrm{mmol})$ and DMAD or NPM $(10 \mathrm{mmol})$ were suspended in $50 \mathrm{ml}$ of benzene. The mixture was heated on a steam bath and triethylamine (10 mmol, dissolved in $30 \mathrm{ml}$ benzene) was then added dropwise in $3 \mathrm{~h}$. The resulting mixture was filtered hot, to eliminate triethylamine bromhydrate. The clear solution was evaporated on a steam bath. The crude products recrystallized from an appropriate solvent for compounds 5 and 7, and for compound $\mathbf{6}$ we done and flash chromatography on silica using dichloromethane-methanol 98:2.

1,2-Dicarbomethoxy-3-styryl-pyrrolo[2,1-b]phthalazine (5). Recrystallized from methanol. Yellow crystals. Yield 75\%, m.p. $122{ }^{\circ} \mathrm{C}$. Anal. $\mathrm{C}_{23} \mathrm{H}_{18} \mathrm{~N}_{2} \mathrm{O}_{4}$ : C: Calcd. 71.50, Found 71.40; H: Calcd. 4.66, Found 4.70; N: Calcd. 7.25, Found 7.00. IR $\left(\mathrm{KBr}, \mathrm{cm}^{-1}\right)$ : v: 1750-1700(s, brooded, with 2 maximum: 1740 and 1725), 1630(s), 1600, 1570, 1510, 1450 (s-m), 1290 (s), 1230, 1130(s-m), $2900(\mathrm{w}), 3100-3000(\mathrm{w}) .{ }^{\mathbf{1}} \mathbf{H}$ NMR $\delta: 8.88$ (s, $\left.\mathrm{H}_{6}\right), 8.23-8.20$ (d, H7, J= 8.3), 7.967.93 (d, $\mathrm{H}_{10}, \mathrm{~J}=8.3$ ), 7.78-7.30 (m, 7H: $\mathrm{H}_{8}, \mathrm{H}_{9}, \mathrm{C}_{6} \mathrm{H}_{5}$ ), 4.86-4.82 (d, $\mathrm{H}_{12}, \mathrm{~J}=13.4$ ), 4.30-4.25 (d, $\left.\mathrm{H}_{11}, \mathrm{~J}=13.4\right), 3.81$ (s, $3 \mathrm{H}: \mathrm{CH}_{3}$ from 2 position), 3.71 (s, 3H: $\mathrm{CH}_{3}$ from position 1$) .{ }^{13} \mathbf{C} \mathbf{~ N M R} \delta$ : $175.9\left(\mathrm{CO}, \mathrm{C}_{1 \mathrm{a}}\right), 174.8\left(\mathrm{CO}, \mathrm{C}_{2 \mathrm{a}}\right), 166.27\left(\mathrm{C}_{6}\right), 151.92\left(\mathrm{C}_{10 \mathrm{~b}}\right), 141.32\left(\mathrm{C}_{6 \mathrm{a}}\right), 137.62\left(\mathrm{C}_{10 \mathrm{a}}\right), 133.96$ $\left(\mathrm{C}_{13}\right), 132.64\left(\mathrm{C}_{9}\right), 131.98\left(\mathrm{C}_{8}\right), 130.01-129.40\left(\mathrm{~m}: \mathrm{C}_{7}, \mathrm{C}_{10}, 2 \mathrm{C}_{14}, 2 \mathrm{C}_{15}\right), 128.09\left(\mathrm{C}_{16}\right), 127.35$ $\left(\mathrm{C}_{12}\right), 126.26\left(\mathrm{C}_{11}\right), 123.92\left(\mathrm{C}_{3}\right), 116.16\left(\mathrm{C}_{2}\right), 103.38\left(\mathrm{C}_{1}\right), 52.73\left(\mathrm{C}, \mathrm{CH}_{3}\right.$ from 2 position $), 51.14$ (C, $\mathrm{CH}_{3}$ from position 1$)$.

5,6-Dicarbomethoxy-3-methyl-7-styryl-pyrrolo[1,2-c]pyrimidine (6). Recrystallized from methanol then flash was doing. Brown-yellow compound. Yield 21\%. Anal. $\mathrm{C}_{20} \mathrm{H}_{18} \mathrm{~N}_{2} \mathrm{O}_{4}$ : C: Calcd. 68.57, Found 68.45; H: Calcd. 5.14, Found 5.20; N: Calcd. 8.00, Found 7.60. IR (KBr, $\mathrm{cm}^{-1}$ ): $v$ : 1750-1700(s, brooded, with 2 maximum: 1735 and 1720), 1630(s), 1560, 1505, 1460 (sm), 1290 (s), 1230, 1130(s-m), 2900 (w), 3100-3000(w). ${ }^{1}$ H NMR $\delta: 8.05$ (s, H H $_{1}$, 7.60-7.20 (m, $\left.6 \mathrm{H}: \mathrm{H}_{4}, \mathrm{C}_{6} \mathrm{H}_{5}\right), 5.00-4.80\left(\mathrm{~d}, \mathrm{H}_{9}, \mathrm{~J}=13.0\right), 4.30-4.10\left(\mathrm{~d}, \mathrm{H}_{8}, \mathrm{~J}=13.0\right), 3.80$ (s, 3H: $\mathrm{CH}_{3}$ from 6 
position), 3.60 (s, 3H: $\mathrm{CH}_{3}$ from 5 position), 2.60 (s, 3H: $\mathrm{CH}_{3}$ from 3 position).

3-Styryl-10-b-H-pyrrolino[2,1-b]phthalazinium-1,2-dicarboxylic acid $\mathrm{N}$-phenylimide (7). Recrystallized from methanol. Cream crystals. Yield 79\%, m.p. 129-130 ${ }^{\circ} \mathrm{C}$. Anal. $\mathrm{C}_{27} \mathrm{H}_{21} \mathrm{~N}_{3} \mathrm{O}_{2}$ : C: Calcd. 77.32, Found 77.26; H: Calcd. 5.01, Found 5.10; N: Calcd. 10.02, Found 9.92. IR $\left(\mathrm{KBr}, \mathrm{cm}^{-1}\right): \mathrm{v}: 1750-1680$ (s, brooded, with 2 maximum: 1735 and 1715), 1630(s), 1600, 1500, 1455, 1400 (s-m), 1290 (s), 2900 (w), 3100-3000(w). ${ }^{1}$ H NMR $\delta$ : 7.65 (s, H6), 7.65-7.61 (d, H, $\mathrm{J}=8.2$ ), 7.55-7.10 (m, 8H: $\left.\mathrm{H}_{8}, \mathrm{H}_{9}, \mathrm{H}_{10}, \mathrm{C}_{6} \mathrm{H}_{5}\right)$, 5.09-5.03 (d, $\left.\mathrm{H}_{10 \mathrm{~b}}, \mathrm{~J}=8.1\right)$, 4.83-4.80 (d, $\mathrm{H}_{12}, \mathrm{~J}=$ 7.6), 4.41-4.32 ( $\mathrm{t}$ and $\mathrm{d}, \mathrm{H}_{3}, \mathrm{~J}=15.2, \mathrm{~J}=7.1, \mathrm{~J}=1.8$ ), 4.24-4.19 (t, $\mathrm{H}_{11}, \mathrm{~J}=15.2, \mathrm{~J}=7.6$ ), 3.79-3.74 $\left(\mathrm{dd}, \mathrm{H}_{2}, \mathrm{~J}=7.1, \mathrm{~J}=6.5\right), 3.71-3.65\left(\mathrm{t}\right.$ and $\left.\mathrm{d}, \mathrm{H}_{1}, \mathrm{~J}=8.1, \mathrm{~J}=6.5, \mathrm{~J}=1.8\right) .{ }^{13} \mathrm{C}$ NMR $\delta$ : 176.84 (CO, $\left.\mathrm{C}_{2 \mathrm{a}}\right), 174.76\left(\mathrm{CO}, \mathrm{C}_{1 \mathrm{a}}\right), 139.94\left(\mathrm{C}_{17}\right), 138.99\left(\mathrm{C}_{6}\right), 137.81\left(\mathrm{C}_{9}\right), 136.20\left(\mathrm{C}_{10 \mathrm{a}}\right), 133.51\left(\mathrm{C}_{13}\right)$, $132.45\left(\mathrm{C}_{6 \mathrm{a}}\right), 130.47\left(\mathrm{C}_{7}\right), 129.29-128.52$ (m: $\left.\mathrm{C}_{8}, \mathrm{C}_{10}, 2 \mathrm{C}_{19}\right), 128.19-127.41$ (m: $\left.2 \mathrm{C}_{14}, 2 \mathrm{C}_{15}\right)$, $126.64\left(\mathrm{C}_{16}\right), 126.27\left(\mathrm{C}_{20}\right), 125.53\left(\mathrm{C}_{12}\right), 124.86\left(2 \mathrm{C}_{18}\right), 122.67\left(\mathrm{C}_{11}\right), 78.98\left(\mathrm{C}_{10 \mathrm{~b}}\right), 72.86\left(\mathrm{C}_{3}\right)$, $50.62\left(\mathrm{C}_{1}\right), 49.59\left(\mathrm{C}_{2}\right)$.

\section{Acknowledgements}

To CNCSIS Bucuresti for financial support.

\section{References}

1. Zugravescu, I.; Petrovanu, M. N-Ylid Chemistry, McGraw-Hill: London, 1976; pp 95-314.

2. Padwa, A. 1,3-Dipolar Cycloaddition Chemistry, John Wiley \& Sons: New York, 1984, vol. 2: chapter 12 (by Padwa, A.) pp 277-406 and Chapter 13 Houk, K.N.; Yamaguchi, K.) pp. 407.

3. Houben-Weyl, Organische Stickstoff-Verbindungen mit einer $C$, $N$-Doppelbindung, Thieme: Stuttgart, New York, 1991, E14b , pp 100- 160.

4. Acheson, R.M.; Foxton, M.W. J. Chem. Soc. 1993, 2218.

5. Krohnke, F. Ber. 1935, 68, 1177.

6. Mangalagiu, G.; Mangalagiu, I.; Humelnicu, I., Petrovanu, M. Eur. J. Org. Chem. 1999, 703.

7. Ungureanu, M.; Mangalagiu, I.; Grosu, G.; Petrovanu, M. Ann. Pharmacceutiques Fr. 1997, 55(2), 69.

8. Mangalagiu, I.; Ungureanu, M.; Mangalagiu, G.; Grosu, G., Petrovanu, M. Ann. Pharmacceutiques Fr. 1998, 56, 181.

9. Dima, St.; Caprosu, M.; Ungureanu, M.; Grosu, G.; Petrovanu, M. Ann. Pharmacceutiques Fr. 1999, 57, 415.

10. Nestorescu, N. Bacteriologie Medicala, Ed. Medicala: Bucuresti, 1965, pp 72-86. 
11. Schoenbek, R.; Kloinstein, E. Ger. Offen., 1973, 2.232.362; Chem. Abstr. 1973, 79, 5359. 